\title{
短繊維強化金属基複合材料の繊維配向度評価方法
}

\author{
今井 義雄*, 塩田 一路**, 篠原 嘉一***, 池 野 進**** \\ (1991 年 6 月 27 日受付)
}

\section{Evaluation of Fiber Orientation in Short Fiber Reinforced Metals}

\author{
Y. IMAI,* I. ShIOTA,** Y. SHINOHARA*** and S. IKENO****
}

(Received June 27, 1991)

\begin{abstract}
Evaluation of fiber orientation in short fiber reinforced metals (SFRM) was attempted. An etched surface at transverse cross section to extruded direction was tilted to observe by SEM. Fiber angle distribution was determined by measuring the fiber angles in the photograph. The distribution was expressed by a simple form of $Y=100 /\left(1+X^{m}\right)$, and $m$ shows the degree of orientation. This method is easy and reliable to evaluate the fiber orientation in SFRM, and is useful to standardize the evaluation method.
\end{abstract}

\section{1. 緒}

現在, 短瀻維強化型金属基複合材料 (SFRM) の実用

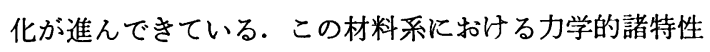
に関しては均一材料と異なる挙動を示すことが多いしし かし, それらの試験法については, 国内での SFRM 独 自の規格はまだ作られていないため，均一材料に関する 試験法を適用することが多い。

一方, この材料系の力学的特性は, 繊維体積含有率, アスペクト比, 繊維の配向性の程度 (以下, 配向度と称 する）などに強く依存する.したがって直接的な力学特 性の測定と同時に，しばしばこれらの測定が必要となる が，これらに対しても定量的な評価方法がない。

短瀻維強化型複合材料は, その使用笝所の応力分布に 応し，製造工程において強化瀻維の方向を三次元ランダ ムから一方向配向まで幅広く制御することができる．特 に一方向に応力が加わる場合, 押出しなどの加工を施し, 強化繊維の配向を応力方向に揄えることが行われる.こ

\footnotetext{
*-***** 金属材料技術研究所機能特性研究部 (153 東 京都目黒区中目黒 2-3-12)

Physical Properties Research Division, National Research Institute for Metals, 2-3-12, Nakameguro, Meguro-ku, Tokyo 153, Japan

*-*** 第 5 研究室 5 th Laboratory

$*$,*** 研究員 Researcher, ** 室長 Head

**** 主任研究官 Senior Researcher
}

のような場合，配向度を知ることは特に重要となる。

現在，配向度については断面の目視観察から「90\% の配向度」などと感覚的な評価がなされているのみであ る. 目的の方向に向いている繊維を $0^{\circ}$, 全く目的の方 向と異なるものを $90^{\circ}$ とすると, この評価では「全部 の繊維のらちの $90 \%$ の本数が $0^{\circ}$ 方向に配向している」 のか, それとも「全部の繊維が目的の方向に対して $90 \%$, すなわち $9^{\circ}$ 方向に配向している」のか, などの区別が できない.

これらは似ているようであるが，全く異なる．前者は 応力方向と繊維方向が一致している繊維数が $90 \%$ ある のですべての䋐維が $0^{\circ}$ に配向しているときの ROM 值 の $90 \%$ の強度が期待できるのに対し, 後者では繊維と 母材の界面での剪断が影響し，著しく低くなると考えら れる1).この例からも明らかなよらに配向度について， その测定方法, 評価方法を明らかにしておくことは重要 である.

配向度を測定する方法としては, 試料を切断, 研磨し た表面を観察・測定する力法 (以下, 平面観察と称する), 加工方向に垂直の断面を腐食し, 突出した緎維の偏倚角 を锥祭・测定する方法（立体観察と称する）がある.

そして, 平面微察では以下に示す方法がある.

(1) 配向方向に平行の面上で配向軸からの偏倚角を測 定する直接観察法

（2）ステレオロジーの理論を応用して二次元の情報か ら三次元の構造を解析する方法 
さらに, (2)のステロオロジーの応用については, 配向方 向に平行な面について，その上に引いた平行線を回転さ せ，纎維との交点を測定する，そして回転角と交点数の 関係を求める方法2， また配向方向に平行な面と垂直の 面について，それらの面上に引いた平行線と䋐維の交点 を測定し，配向度を解析する方法ふなどがある。

これらの平面観察の場合, 研磨 - 腐食時に, 観察面に 平行に近い繊維が重点的に脱落する可能性が大きいま た，(1)は繊維の観察可能な高倍率では 1 視野中の測定の 対象となる繊維の本数が少なく，データ処理に必要な数 十〜数百本の観察可能な繊維を確保するためには多くの 視野を必要とする。

一方，立体観察には，ステレオ投影法により偏倚角を 測定する方法がある4)。このステレオ投影法による測定 方法は，まず同一視野について異なった方向から 2 枚の 写真を撮影する．それらの画像上で詨応する 1 本の繊維 を選び, その繊維上に存在する特徵的な 2 点に着目する。 これら 2 画像・4 点の座標からその繊維の偏倚角を求め る.これは繊維の実際の偏倚角を測定する場合には優れ た方法であるが，多数の繊維を測定するには熟練者であ つても長時間を必要とする。

以上に対し，突出した繊維を傾斜させて撮影した 1 画 像から偏倚角を測定する方法が考光られる。この場合， 多くは平面に投影された繊維について央測することにな る. したがって測定值は実際の偏倚角之は異なる角度と なるが，撮影角度は既知であり，それを固定すれば，評 価上には問題を生じないと考えられる。また試料の作製 が容易であり, 測定も短時間で行えるなどの特長がある。

さらに，配向度を偏倚角の平均值で表した場合，その ときの偏倚角分布に関する情報は表れていない。したが って，この影響も知るためには，偏倚角の分布状態を表 せることが望ましい。

ところで，規格化を目的とする場合，正確な值を得る ことは重要であるが，それと同時に試料作製が容易であ ること，測定に特殊な機材，特殊な技術を用いずとも， 信頼できる值が得られることが重要である。そこで本報 告では 1 万向配向短㵶維強化金属基複合材料について, 規格化を目的とした立体観察の 1 画像による䋊維配向度 の定量的評価方法の検討を行らこととした.

\section{2. 実 験 方 法}

供試材は $\mathrm{SiC}$ ウィスカー強化 6061-A1 合金を 1: 16 の断面減少率で押出したものを用いた，押出し成形の場 合，ダイスの壁面に接する部分ではマトリックスの塑性

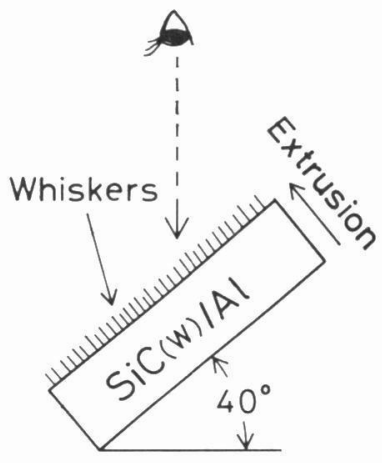

Fig. 1 Schematic model of tilted sample in SEM.

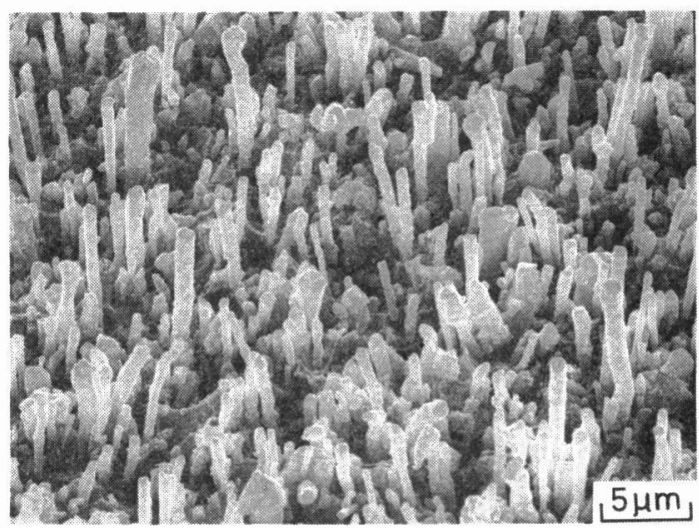

Fig. 2 SEM micrograph (part) for tilted sample $\left(40^{\circ}\right)$.

流れによって緎維の配向度は高くなるが，試料中心部で は, その影響が小さい5). 寸なわち, 試料中心部につい て繊維配向度を評価することにより，全体の配向度はそ れ以上であることが保証される，以上より，本実験では 供試材中心部から観察用の試料を採取した.

試料調製は, まず径 $52 \mathrm{~mm}$ の供試材中心部近傍から $1 \mathrm{~cm}$ 立方の試料を切り出した.

この試料の押出し方向に対する垂直断面を $1 \mu \mathrm{m}$ のダ イアモンド砥粒まで研磨した，この面を $3 \% \mathrm{NaOH}$ 水 溶液により室温で deep etching 乙, 約 $10 \mu \mathrm{m}$ 程度ウ ィスカーを突出させ，観察面とした。この観察面を Fig. 1 の模式図に示すよらに $40^{\circ}$ 傾斜させ, SEM により写 真揖影を行った．この写真を試料寸法の 3,000 倍に引き 伸ばした画面 $(18 \times 24 \mathrm{~cm})$ 上の繊維について押出し方 向に対する偏倚角を測定した。

測定繊維は，客観的に抽出を行らため，写真に繸 20 


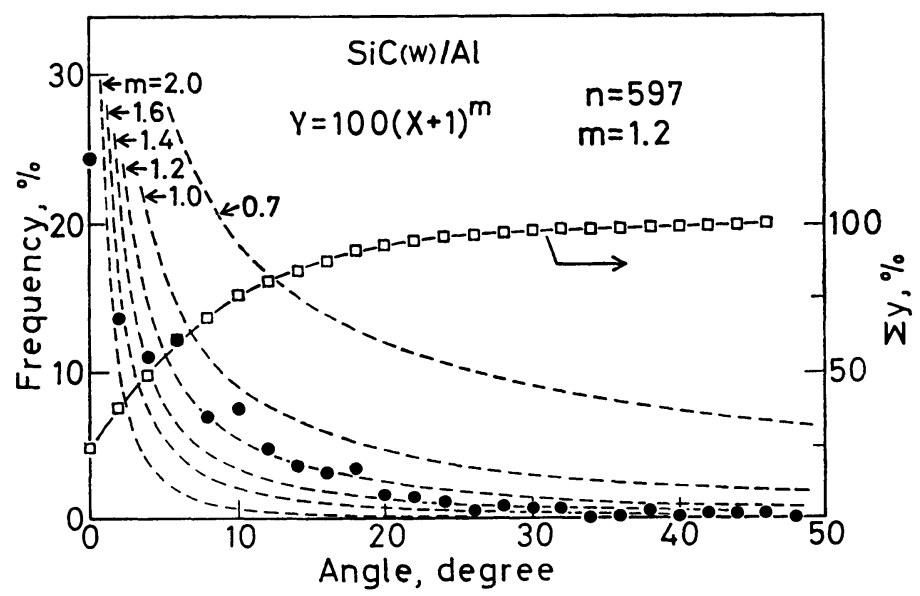

Fig. 3 Frequency and cumulative frequency $v$ s. deflection angle and model curves for various $m$ values.

本，横 10 本の等間隔のメッシュをきり，その交点にあ って，方向が明らかな緘維で長さと直径の比が 2 以上の ものを対象とした．すなわち極端に曲がっている緘維は 方向の測定に適せず，また観察できる繊維の長さと直径 の比が 2 以下の場合, 測定精度に問題があるので, それ らは測定の対象外とした。 また 1 本の緘維が 2 交点上に またがる場合は 1 本と数えた.このように測定した結果, 対象㵶維数は交点数の $50 \%$ 程度となった.

偏倚角は写真上の押出し方向を基準 $\left(0^{\circ}\right)$ として画面 上の繊維の角度を $0.5^{\circ}$ の精度で測定した．具体的には Fig. 2 における垂線に対して，各ウィスカーの方向が左 右に何度偏倚しているかを測定する. また配向度が強度 に与える影響は，十方向と一方向が同等と考兄られるの で絶対角を用いた。

\section{3. 結果および考察}

測定に用いた SEM 写真はかなり大きく,かつその画 面には数百本の㵶維が存在するので, Fig. 2 にはその面 積の $1 / 4$ 程度のみを示す.この写真にみられるように, ほとんどの緘維は押出し方向に向いている.

同様の写真 6 視野, 合計 597 本の㵶維についての偏倚

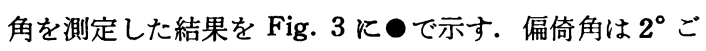
とに分け, 各偏倚角に批ける繊維の頻度を百分率で示し た. また同図にロで果積頻度を示した。この結果にみら れるように, 低偏倚角の絨維の頻度は高く, 偏倚角の增 加と共に頻度が減少するが, $30^{\circ}$ 以上の高偏倚角まで 0 とはならない。この実測結果は, Fig. 2 の目視の感覚よ りも明らかに高偏倚角の㵶維が多い。
次に配向度を適当なパラメータを用いて評価するため には，Fig.3 の分布を数量的に表現する必要がある. 分 布を表すには正規分布, Poisson 分布など種々の関数が あり，それぞれ物理的背景を持つ. しかし Fig. 3 の分 布は実態の繊維配向の分布を示しているのではない，例 えば写真上で $0^{\circ}$ と測定された繊維は, 観察方向と試料 法線の作る面内で法線に対し $0^{\circ} \sim \pm 90^{\circ}$ の範囲に存在 しており，物理的な意味を示していない。したがって上 述のような関数に必ずしも合致しない。

そこで，あらたに Fig. 3 の・で示した分布を適当な 関数で表示する必要が生ずる.この表示は多くのパラメ 一タを用いれば実測値と合致させることは可能である が，規格化を目的とする場合には可及的に簡単に表示す る必要がある.

ところで偏倚角が $5^{\circ}$ 以下の瀻維に対しては, その長 手方向に応力が加わるので, 複合材料の強度に与える影 響が少ないと考えられる.ところが $5^{\circ}$ 以上の偏倚角に なると繊維と母材の界面剪断強度が大きく影響してく る11. また Fig. 3 の累積頻度から明らかなように, 偏 倚角の $15^{\circ}$ までに測定繊維数の $80 \%$ が存在してい る.したがってその範囲の繊維により複合材料の特性が 定められるといえる。これらより偏倚角が $5^{\circ} \sim 15^{\circ}$ ま での範囲で一致する関数を用いて, その材料の擮維配向 度を評価して差し障りがないと考えられる．その範囲の 曲線を近似する関数として次式を検討した。

$$
Y=100 /\left(1+X^{m}\right)
$$

ここで $X$ は偏倚角を度単位で表し， $Y$ はその偏倚角に 存在する纎維の頻度を百分率で示す数值である. また分 


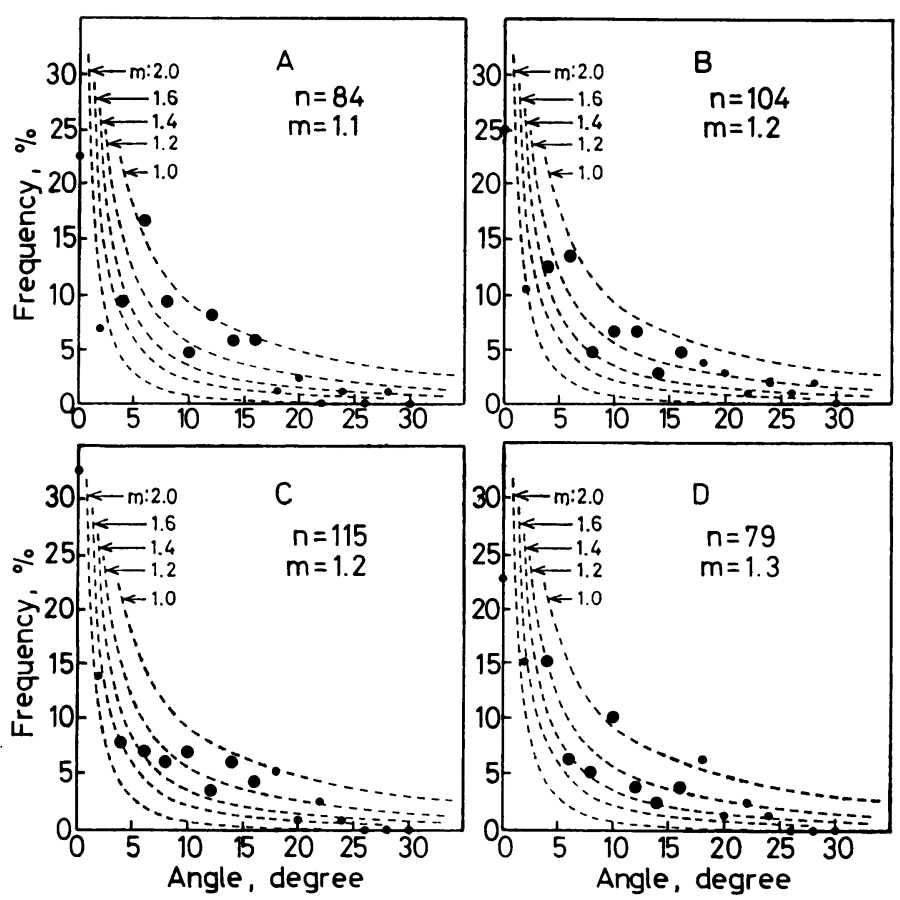

Fig. 4 Frequency vs. deflection angle for approx. 100 whiskers.

母と分子の定数として, 完全配向している場合に頻度の 最大值を $100 \%$ に合わせるために分母に 1 を加えると ともに分子を 100 とした．ｍは纎維配向度を表すパラメ 一タである. (1)式の $m$ 值を 0.7 から 2.0 まで変化させ たときのそれぞれの曲線を Fig. 3 亿破線で示す。この mの值が大きい注ど，配向度が高いことを示す，すなわ ち $m$ 值は配向度を示すパラメータといえる. Fig. 3 に示 すように, (1)式では測定データのすべてが全範囲で一致 する $m$ 値の曲線はない。しかし目的とする $5^{\circ} \sim 15^{\circ}$ の範 囲については $m=1.2$ の曲線とほぼ一致している.すな わち，この表示方法によると，配向度は $m=1.2$ とな る.

次に, この表示方法の場合, 評価が可能な緘維の測定 数について検討を行った. Fig. 4 飞 Fig. 3 を求めると きに用いた 6 視野のうち 4 視野の頻度分布と(1) 式によ る曲線および $\boldsymbol{m}$ 值を示す．各視野に打ける䄉維の測定本 数は 79 115 本で，それぞれ $m=1.1 ， 1.2 １ .2,1.3$ である.これらの值はいずれも Fig.4 の約 600 本の緎 維についての $m=1.2$ の值に対して \pm 0.1 の範囲にあ る.この範囲は Fig. 4 に示した ほど大きな䛊差ではない，以上より配向度は，100 本の 繊維の測定により必要・十分な精度で評価を行うことが
できると考えられる。

\section{4. 結}

論

繊維配向度の規格化を目的として，繊維配向性を客観 的に，かつ短時間で容易に行える評価技術について検討 した。そ結果,

1）試料作製は加工方向に垂直断面で纎維を突出させ る.

2）繊維の偏倚角分布は，上記試料面を傾斜撮影した 一枚の写真から短時間で容易に測定できる.

3）パラメータがーつだけの簡単な関数， $Y=100 /(1$ $\left.+X^{m}\right)$ を適用し， $m$ 值により緎維配向度を評価 しうる.

4）本評価方法では測定繊維数が 100 本程度で十分の 精度が得られ， 1 視野でその測定数を確保できる.

この方法は䋐維を配向させることを目的として作成し た短緎維強化複合材料を対象として考穴たものであり， 実際の加工方向からの偏倚角を求めていないが, 配向度 を評価する一つのパラメータとして簡単，かつ有用な方 法と考兄られる。

本研究は，(財)大阪科学技術センター付属ニューマテ 
リアルセンターによる平成 2 年度通商産業省工業技術院 依託「石油代替電源用新素材の試験・評価方法の標準化 に関する調査研究」の一環として行った. 本研究を遂行 するにあたり，多くのご示唆をいただいた工業技術院大 阪工業技術試験所沢田吉裕氏に深甚なる感謝の意を表し ます.

$$
\text { 参考文 献 }
$$

1) P.W. Jackson \& D. Cratchley : J. Mech. Phys.
Solids, 14 (1966), 49-64.

2) 末永和之, ほか: 第 105 回日本金属学会講演概 要, (1989), p.727.

3) 大沢直志 : 複合材料 (化学総説 No. 8, 日本化学 会編), 東京大学出版会, 東京 (1975), pp. 7488.

4) D. Hull 著, 宮入裕夫, 注共訳 : 複合材料入門, 培風館, 東京 (1984), pp. 54-73.

5) 平井恒夫 : 現代化学 増刊 8 新しい複合材料と 先端技術, 東京化学同人, 東京 (1986), pp. 187195. 